\title{
Surface tailings disposal at the Żelazny Most TSF, today and into the future
}

\author{
Paweł Stefanek KGHM Polska Miedź, Poland \\ Jon Engels Tailpro Consulting, Chile \\ Krzysztof Wrzosek Warsaw University of Technology, Faculty of Building Services, Hydro and \\ Environmental Engineering, Poland \\ Przemysław Sobiesak DHV Hydroprojekt, Poland \\ Michał Zalewski DHV Hydroprojekt, Poland
}

\section{Abstract}

The Żelazny Most Tailings Storage Facility (TSF) is currently the sole site for the deposition of tailings generated from the flotation process of copper ore, which is extracted by KGHM Polska Miedź. The Żelazny Most TSF was commissioned in 1977.

At the present time, the Tailings Storage Facility (TSF) occupies an area of 1638 ha having an embankment perimeter of $14.3 \mathrm{~km}$, making it one of the largest tailings facilities in Europe. The current height of the embankments range from 40 to $71.5 \mathrm{~m}$ (maximum crest elevation is $182.5 \mathrm{~m}$ asl) and approximately 600 million $m^{3}$ of tailings have already been deposited within the facility to date.

Currently, the Żelazny Most TSF is being raised up to an elevation of $195 \mathrm{~m}$ asl. As a result, it will be capable of storing 770 million $\mathrm{m}^{3}$ of tailings by 2037. Since 2008, KGHM has been preparing conceptual studies of future tailings storage methodology to ensure deposition until 2042 (1 billion $\mathrm{m}^{3}$ ). With having a focus on safety and the environment, it was concluded that the future development of the Żelazny Most TSF will be carried out by constructing the Southern Extension (609 ha) adjoining the Main Structure to the south. DHV Hydroprojekt and KGHM have performed several studies focused on the construction methodology of the embankments for the new Southern Extension. The conclusion of these studies is to convert the tailings disposal from unthickened upstream spigotting construction, to thickened tailings deposition. Under this scenario, part of tailings would by segregated by means of hydrocyclones, allowing the coarse fraction to be used for downstream embankment construction and the fine fraction thickened and deposited in the central section of the Southern Extension.

This paper presents the development of the Żelazny Most TSF facility to date and the options studied as part of the Southern Extension development and migration to thickened tailings storage.

\section{Introduction}

KGHM Polska Miedź S.A. (KGHM) is a world class underground copper and silver operation located in southwest Poland operating since 1961. 
KGHM is a global producer of copper and silver with over 50 years of experience owning one of the largest copper deposits in the world. KGHM has guaranteed continued production in Poland for the next 40 years. Copper ore mining in Poland is concentrated in three mines: 'Lubin', 'Rudna' and 'Polkowice-Sieroszowice', ore is processed in the Ore Processing Facilities located in the vicinity of mines and production of copper, silver and other products takes place at smelters in Głogów and Legnica and the rolling mill 'Cedynia'.

All of the ore extracted from the mines of KGHM is sent to the Ore Enrichment Division comprised of three ore enrichment plants (OEP) of varying capacity, located at each mine. All of the enrichment facilities use the same basic methods and processes. However, due to the varying quality of the ore which is processed, each of the facilities applies these methods in fundamentally different ways. These methods are comprised of crushing, milling and classifying, flotation, thickening and filtration, and drying. The tailings generated by this process are in the form of a slurry, in which solids represent 7 to $9 \%$ by volume. These tailings are transported by pipelines to the Żelazny Most TSF where the solids settle out in the pond, while the clarified water is then re-cycled back to the ore enrichment process. Water therefore is continuously circulating between the OEPs and the tailings pond.

Table 1 OEP tailings production

\begin{tabular}{cccccc}
\hline Parameter & Unit & OEP Rudna & OEP Polkowice & OEP Lubin & Total \\
\hline Nominal production rate & $\mathrm{t} / \mathrm{h}$ & 1,600 & 915 & 810 & 3,325 \\
Annual tailings production & $\mathrm{t}$ & $13,900,000$ & $7,800,000$ & $6,900,000$ & $28,600,000$ \\
Solids concentration of discharged tailings & $\%$ sol. by mass & 20.7 & 18.3 & 13.1 & - \\
Specific gravity of tailings & $\mathrm{kg} / \mathrm{m}^{3}$ & 2.65 & 2.70 & 2.64 & - \\
Length of pipelines to TSF Żelazny Most & $\mathrm{m}$ & 5,000 & 7,800 & 8,300 & - \\
Pipe sizes & & 2xDN1300 & 2xDN1100 & $3 x D N 700$ & \\
\hline
\end{tabular}

\section{2 Żelazny Most Tailings Storage Facility}

\section{1 Żelazny Most TSF location and overview}

Żelazny Most TSF is one of the largest facilities of this kind in the world. It is currently the sole site for the discharge of tailings generated during the flotation process of copper ore, which is extracted by KGHM. It is situated in the south-west of Poland, in the vicinity of the towns of Lubin and Głogów, at a distance of approximately $80 \mathrm{~km}$ from the city of Wrocław. The natural ground depression in the south-eastern portion of the Dalkowskie Hills played the most important role in the selection of the location of the tailings deposit.

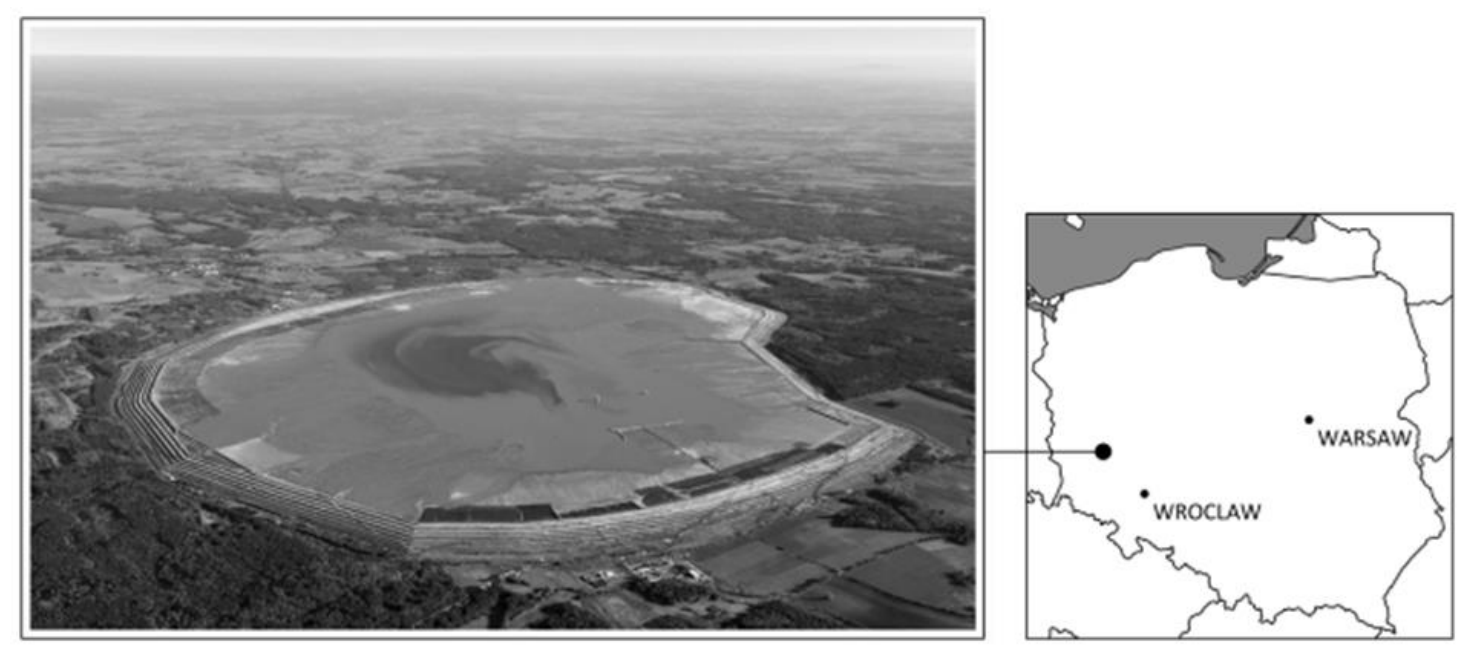

Figure 1 The location of the Żelazny Most Tailings Storage Facility 
The area of Żelazny Most TSF is mainly adjacent to woodland and arable land. The closest populated areas are: Tarnówek village (600 $\mathrm{m}$ to the west of the site boundary), Grodowiec village (1,500 $\mathrm{m}$ to the north of the site boundary), Rudna village $(1,000 \mathrm{~m}$ to the east of the site boundary) and Rynarcice village $(1,500 \mathrm{~m}$ to the south of the site boundary).

The construction of the TSF started in 1974 with discharge of tailings commencing in 1977. The ring dams surrounding the disposal area are $14.3 \mathrm{~km}$ long. The basic facility parameters are as follows:

- Total volume of TSF

$\left[\mathrm{m}^{3}\right]$

$604,000,000$

- Volume of deposited tailings $\left[\mathrm{m}^{3}\right.$

$597,000,000$

- Volume of decant pond

$\left[\mathrm{m}^{3}\right]$

$7,000,000$

- Total area of TSF

$\left[\mathrm{m}^{2}\right]$

$16,380,000$

- Dams height

[m]

$40-71.5$

The whole transport system of tailings and process water for Żelazny Most TSF includes almost 100,000 m of pipelines.

Tailings from three Ore Enrichment Plants (OEPs) are stored within the Żelazny Most TSF, each being delivered by independent pipeline networks. The tailings are pumped to the TSF as low concentration slurry and discharged sub-aerially via spigotting around the entire perimeter of the TSF embankment crest. Sand recovered from the tailings is used for embankment construction utilizing the conventional upstream construction technique. Clarified water from the decant pond is returned to the OEPs.

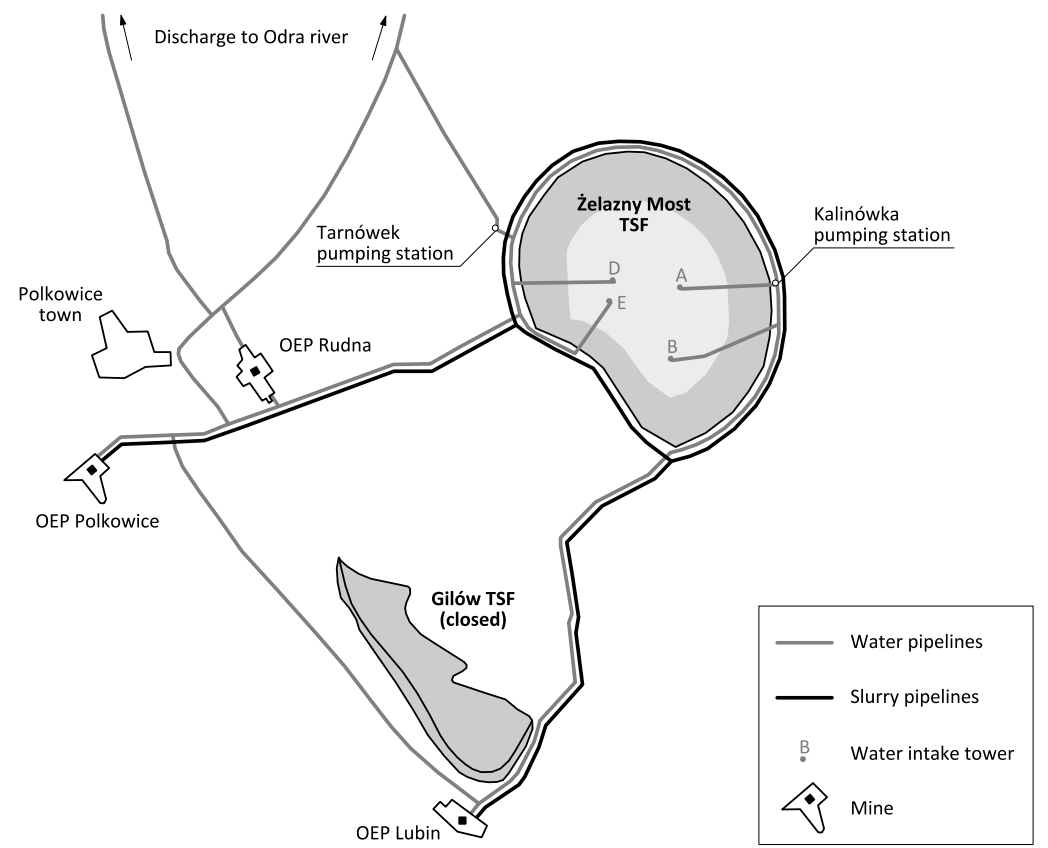

Figure 2 Pipelines network of the Żelazny Most TSF

\section{$2.2 \quad$ Local geology}

The general geological sequence in the region of Żelazny Most TSF, from the ground surface downwards, is:

- Superficial solifluction deposits (which do not occur everywhere).

- Quaternary deposits (Pleistocene glacial outwash sands and gravels; stiff clays).

- Neogene deposits (generally stiff clays). 
The Quaternary deposits were laid down by ice sheets that advanced from the northwest and moved over the Neogene clays. The ice sheets were also responsible for the deposition of materials, particularly granular, which had been picked up by the ice as it advanced southeastwards. The disturbance to the Neogene clays is very considerable, often resulting in the older Neogene clays being thrust over the younger Quaternary soils. The over-thrusting by the ice sheets, referred to as 'glaci-tectonics', is of considerable importance for

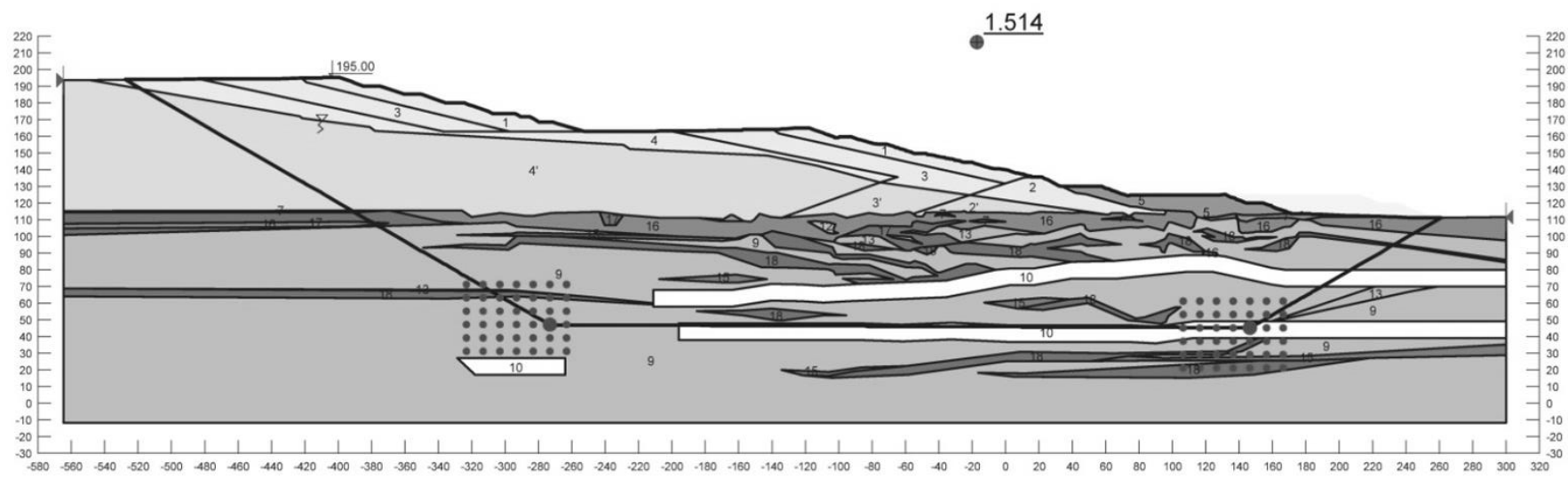

the stability of the dam, as the thrusting caused during its formation of extensive shear surfaces in the more plastic of the Neogene clays, which have a low strength, referred to as the 'residual strength'.

Figure 3 Cross-section of the dam and foundation soils (results of the static analysis)

The orientation of the major shear surfaces within Neogene clays is expected to be from the northwest towards the southeast as it is the general direction of the Quaternary ice movement.

Two main types of glaci-tectonics in the plastic Neogene clays have been identified: 'horizontal thrusts', and 'inclined thrusts', and both of them should be assumed to have resulted in extensive shear surfaces. In view of the very considerable deformations involved in the glaci-tectonics structures, it is imperative that the residual strength of the Neogene clay is taken into account in assessing the stability of the dam.

The Quaternary deposits are largely sands and gravels, deposited on the surface of the Neogene soils as outwash from the Pleistocene ice-sheets. The subsequent glaci-tectonics resulted in large lenses on tongues of gravels being thrust into the previously underlying Neogene clays. The engineering consequence of this is that the ground water conditions in the dam foundations are controlled by the often very complex geometric arrangement of the gravels, providing drainage boundaries to the masses of Neogene clay.

Just below the surface of the existing ground there are superficial layers, usually no thicker than about $2 \mathrm{~m}$, composed of soliflucted clays and other soils. The three categories of solifluction (low, medium, and high intensity), and clays without solifluction structures' ('cryoterbatet clay') have been identified. Cryoterbatet clays do not contain the shear surface that is characteristic of soliflucted deposits.

Solifluction soils have been formed as a result of freeze-thaw processes (during or at the end of the Pleistocene) and as a consequence have, particularly on slopes, moved as 'mud-slides'. Shear surface or slicken-sided surfaces have been formed because of this sliding. This process will be referred to here as 'solifluction'. As a result of their mode of formation, soliflucted soils may be regarded as being re-worked, of either Neogene or Quaternary origin, depending on the soil type which occurs at the ground surface. The areas of solifluction are generally of limited extent. The detailed investigations show that shear surfaces in the soliflucted clays are rather infrequent, discontinuous, and rarely inclined in a direction critical for the stability of the dam.

\subsection{Construction of the dam, tailings parameters, and observational method}

Tailings of coarser granulation from Lubin and Rudna are spigotted from the dam crests, creating beaches of gentle slopes (about 1\%) towards the site's central area. From the $\varnothing 800 \mathrm{~mm}$ pipelines located on the crests, 
tailings are consecutively discharge from sections of about $500 \mathrm{~m}$. The much finer Polkowice tailings are transported to the site's central part through pipelines laid on piers comprised of earth fill structures, perpendicular to the dams. The piers pipes are also used for the spigotting of the Lubin and Rudna tailings during the winter, when low temperatures occur.

Such a deposition system results in reduction in the amount of additional building materials utilized during the development of Żelazny Most. The soil, conventionally used during the construction of dams, is here replaced by classified tailings.

The TSF is raised in stages of $2.5 \mathrm{~m}$. The rate of rise is approximately $1.5 \mathrm{~m} / \mathrm{y}$. Therefore, the raising stages follow each other in two-year intervals. The adopted deposition system causes the coarse tailings to remain on the beach, near the crest from where they are excavated for the dam construction. At the same time, fine-grained (dusty) tailings flow into the pond, where they form a virtually impermeable bowl underneath the water table. The bowl restricts the water infiltration into the original ground. Observations proved that only $6 \%$ of seepage occurs into the ground beneath the pond, while the remaining $94 \%$ infiltrates through the beaches and is captured by the drainage system. The site is equipped with an extensive drainage system, consisting of:

- A ditch at the dam's toe.

- Starter dam drainage and additional (auxiliary) drainage.

- Circumferential drainage.

- Vertical drainage (barrier of dewatering wells).

Figure 4 represents a scheme of tailings zoning in the site's embankment, while Table 2 shows selected geotechnical parameters of the soil. An apostrophe next to the zone's name indicates that the parameters refer to a fully saturated material.

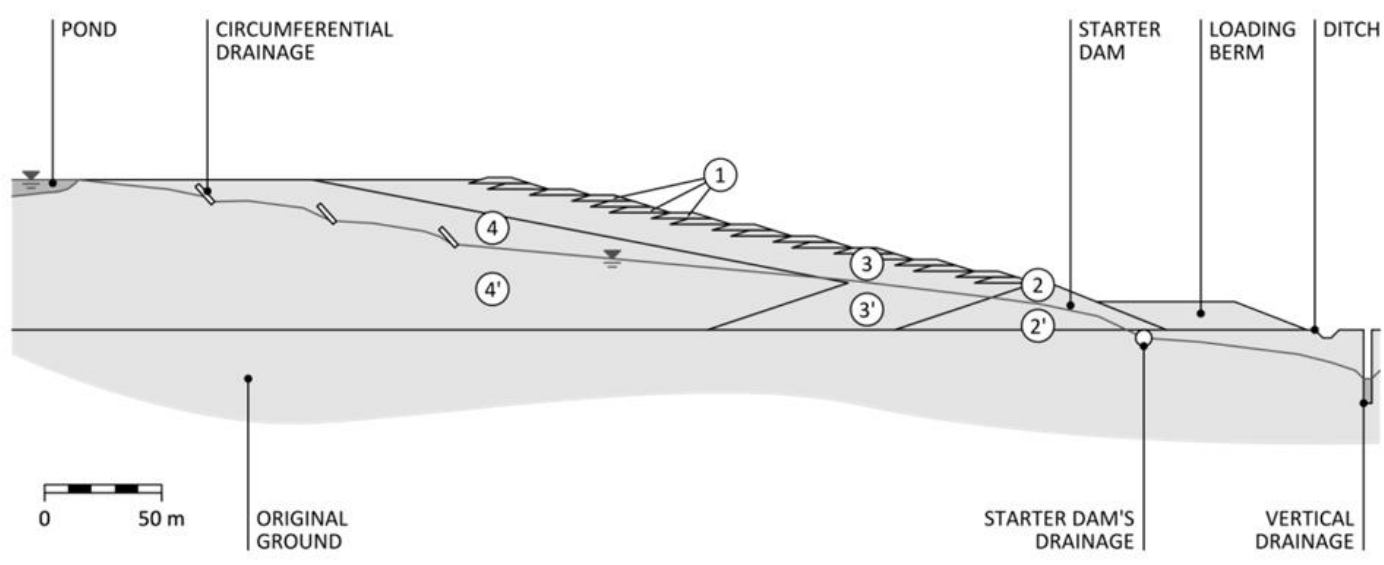

Figure 4 Tailings zoning in the site's embankment 
Table 2 Soil geotechnical parameters

\begin{tabular}{|c|c|c|c|c|c|}
\hline Zone & Material type & $\begin{array}{c}V \\
\left(\mathrm{kN} / \mathrm{m}^{3}\right)\end{array}$ & $\begin{array}{l}\phi^{\prime} \\
\left({ }^{\circ}\right)\end{array}$ & $\begin{array}{c}\mathrm{c}^{\prime} \\
(\mathrm{kPa})\end{array}$ & $\begin{array}{c}\mathrm{Su} \\
(\mathrm{kPa})\end{array}$ \\
\hline 1 & $\begin{array}{l}\text { Embankment } \\
\text { (sandy tailings, mechanically condensed) }\end{array}$ & 19.0 & 34 & 0 & - \\
\hline 2 & Starter dam & 19.0 & 34 & 0 & - \\
\hline $2^{\prime}$ & (natural sands, mechanically condensed) & 20.5 & 34 & 0 & - \\
\hline 3 & Zone I & 18.0 & 34 & 0 & - \\
\hline $3^{\prime}$ & (sandy tailings, not mechanically condensed) & 19.5 & 34 & 0 & - \\
\hline 4 & Zone II & 17.0 & 34 & 0 & - \\
\hline $4^{\prime}$ & (uncondensed dusty tailings) & 18.5 & - & - & $0.35 \sigma^{\prime} \mathrm{V}$ \\
\hline
\end{tabular}

Note: $\gamma$ - unit weight, $\phi^{\prime}$ - effective internal friction angle, $c^{\prime}$ - effective cohesion, $\sigma^{\prime} v$ - vertical effective stress,

$\mathrm{S}_{\mathrm{u}}$ - undrained shear strength

The Żelazny Most TSF has been in constant operation and development since its launch. The design process drew on the experience gained during the construction and operation of the Gilów TSF (closed in 1980), which in turn, benefited from the conclusions drawn from the Iwiny TSF disaster which was caused by a dam failure in 1967.

Due to the water pond being located in the central part of the site, Żelazny Most TSF is considered to be the object of the highest importance class (a 1st class hydrostatic structure according to Polish regulations). The observational design method, adopted worldwide, was recommended by the International Board of Experts, appointed by the KGHM management. Its objective is to use the data obtained from the monitoring during the course of the superstructure design process. Stability is analyzed repetitively, based on the most up to date observations and data.

An observational method in the construction industry allows for assessment of geotechnical parameters in complex geological-engineering conditions on the basis of structural behavior. By using the monitoring results in back analysis, one may assess so called design observational parameters. The parameters, used in the calculations allow for correction of design solutions. The crucial role in the formulation of principles of the observational method application were developed by C. Terzaghi and later R. Peck. They paid attention to the inefficiency of design based on the most unfavorable assumptions (Terzaghi and Peck, 1967). However, accepting design modifications during construction may result in significant savings as design is made on the basis of the most probable not the most unfavorable parameters. Missing information is supplemented by observations made during construction, while design is modified in consistency with obtained data. 


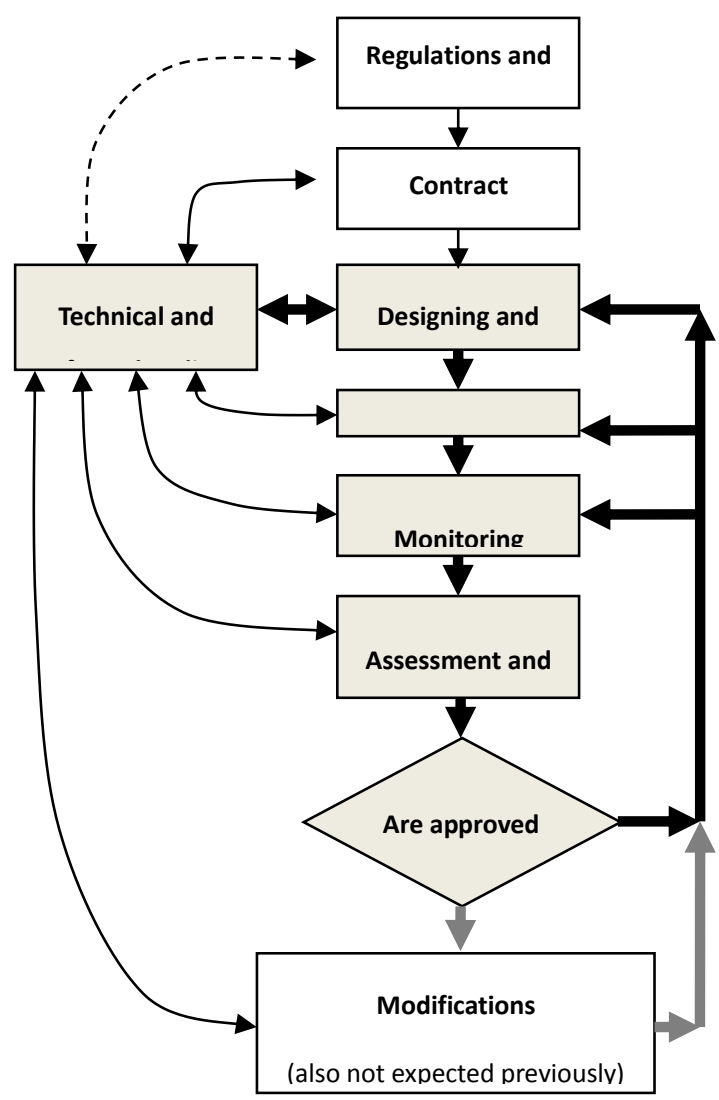

Figure 5 Schema of observational method (Nicholson et al., 1995)

A comprehensive monitoring system tracking various aspects of disposal exploitation includes monitoring of seepage phenomena in the dam body and in the foundation soil, monitoring of horizontal and vertical displacements of dams and foundation soils, of para-seismic activity as well as of some selected ecological parameters. Data from the monitoring system and results of periodic visual inspections are used in the current assessment of the technical state of the facility. The application of the observational method provides potential savings of time or money, while monitoring guarantees safety of the structure.

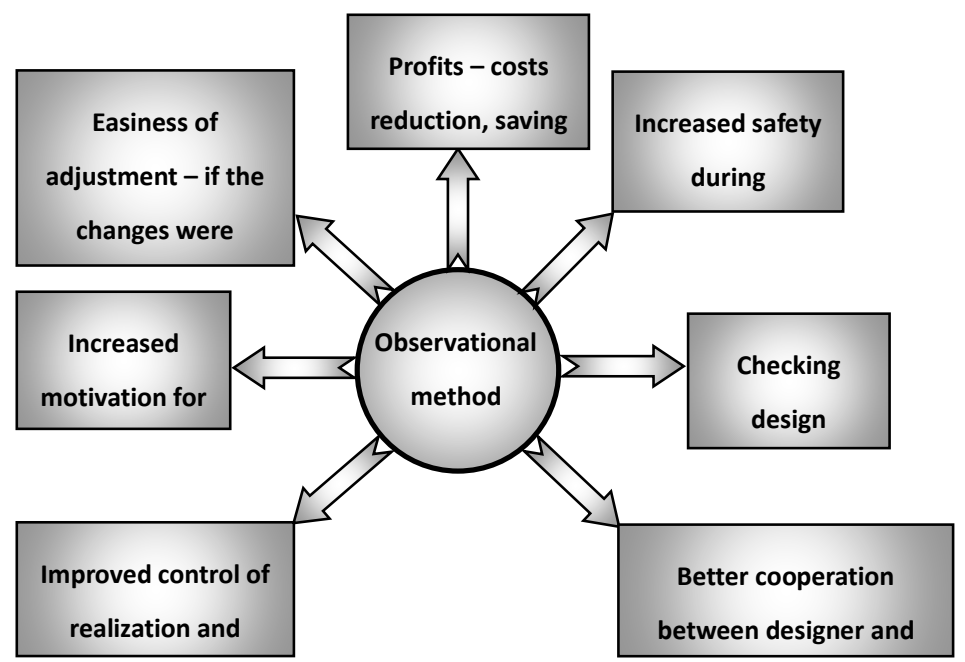

Figure 6 Advantages of application of observational method (Nicholson et al., 1995) 


\section{$3 \quad$ Monitoring system of Żelazny Most TSF}

Geotechnical monitoring of Żelazny Most TSF is critical to determine the safety of the structure and includes:

- Water levels in the pond, foundation soils and monitoring of pore pressure.

- Displacements of dams and foundation soils.

- Drainage and ditch discharge.

- Seismic vibrations.

- Visual assessment of technical state of dams, downstream area, beach, etc.

Geodetic survey - The geodetic survey network aimed at measurements of displacements of dam crest and downstream area includes 439 benchmarks stabilized in the starter dam and within the dam body on the subsequent benches as well as in downstream area at distances from 50 to $500 \mathrm{~m}$ from the crest axis. Buried benchmarks measure settlements of deeper located soil layers induced by dam (or other) loading.

Water level measurement - Approximately 2000 open piezometers are installed on the dams and in the downstream area used for observation of water level changes in the tailings and in the foundation soils.

Drainage discharge measurement - The measurements of discharge from the subsequent drainage nodes or their clusters and their comparison with piezometric level changes in the selected tests points are aimed at:

- Assessment of drainage efficiency in time.

- Register of changes in drainage operation.

- General characterization of seepage phenomena in the dam body in the analysed cross-sections.

- Evaluation of total volume of water collected by drainage (water balance).

Pore pressure measurement - VW piezometers allow for measurement of pore pressure values in one borehole at different levels, defined by the designer. Pore pressure transducers are installed in boreholes, filled with cement-bentonite grout. More than 350 pressure transducers are installed within the deposit (Geonor+Glotzl). Considering this technology it is possible to install a couple of VW transducers in one borehole within inclinometer casing.

Inclinometer measurements - The inclinometer measurements are an essential element of monitoring equipment. The inclinometers are located within selected cross-sections of the dams. The objective of the tests are measurements of horizontal displacements of the top layers of Neogene high plasticity clays in the locations where the highest horizontal displacements induced by dam and tailings load are recorded. Currently, 73 deep inclinometers (from 79 to $160 \mathrm{~m}$ long) and 15 shallow inclinometers (from 20 to $57 \mathrm{~m}$ ) are installed within the disposal area.

Automatic measurements - In order to monitor displacements of the central part of the East dam, an automatic measurement system GeoMoS by Leica was considered. It forms a part of the geodetic survey monitoring. The station carries out measurements of coordinates and levels of 23 mirrors located on the upstream slope of the East dam. The distances between the monitoring station and mirrors varies from approximately $50 \mathrm{~m}$ to more than $600 \mathrm{~m}$.

In addition, eight GNSS monitoring stations were installed in the vicinity of the northern and western dam, which enable continuous geodetic monitoring of the dam section characterized by the greatest displacement speed.

Visual inspections - Apart from measurements of monitoring equipment, it is extremely important to carry out constant visual inspections of the dams. The visual assessments of the state of tailings disposal are based on walkover inspections of the dams and other elements that impact safety of the facility. The frequency of detailed inspections are typically every 2 to 4 weeks. 


\section{$4 \quad$ Research to enlarge storage capacity}

The current life of mine plan to 2050 indicates a need to create additional tailings storage capacity of more than $400 \mathrm{M} \mathrm{m}^{3}$ which, combined with the amount of tailings already deposited gives almost 1 Billion $\mathrm{m}^{3}$. Deposition of tailings in the Żelazny Most TSF is limited by permit to build the dams crest up to the elevation of $195 \mathrm{~m}$ asl, which corresponds to the total volume of tailings, approximately $750 \mathrm{M} \mathrm{m}^{3}$, this volume will be reached by the end of 2026.

Deposition of all tailings in the TFS Żelazny Most would require a dam increase to the elevation of approximately $210 \mathrm{~m}$ asl. The height of the dam would reach almost $90 \mathrm{~m}$, however, indications from control equipment, in particular the large horizontal displacement rate on certain sections of the dams, indicate this variant raising very risky.

DHV Hydroprojekt has defined three basic variants for further TSF development.

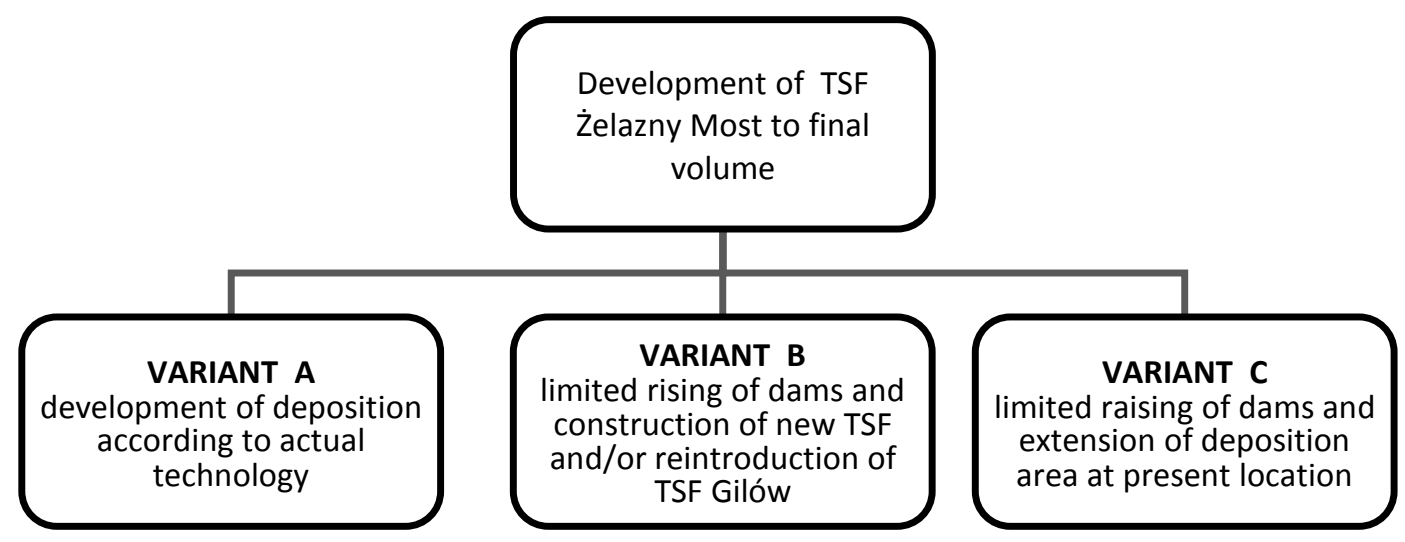

Figure 7 Variants of the Żelazny Most TSF development

\subsection{Development of TSF Żelazny Most as the only deposition site - Variant A}

Variant envisage the construction of stabilizing 'Mega Berms' on the North and West sides of the TSF Żelazny Most, in addition to the "Mega Berm" currently designed on the East side or that the 'Mega Berm' would be constructed only on the East side and the dam axis would be shifted inward $150 \mathrm{~m}$. The dam crest would be raised to $210 \mathrm{~m}$ asl and maximal height of the dams would reach $90 \mathrm{~m}$.

Further increasing of the dams above elevation of $180 \mathrm{~m}$ asl, along with proposed dam stabilizing operations is the less costly method of reaching additional storage capacity, however, the lack of reserve capacity with simultaneous risks associated with dams safety disqualify this option and forces seeking other alternatives which will give KGHM security and confidence of uninterrupted copper production.

\subsection{New additional TSF - Variant B}

A required storage area that is closely linked with current depositing technology and storage facility design. Therefore, the required total storage area of a new TSF while maintaining the conventional technology should correspond to an area of the Żelazny Most TSF, approximately 1,200 hectares. The Gilów TSF area within the KGHM property was determined and is about 600 hectares however, studies have shown there is a possibility of extending the surface of the Gilów TSF up to approximately 850 hectares. 
Table 3 New TSF area considering current depositing technology

\begin{tabular}{cccc}
\hline & & Conventional tailings & Thickened tailings \\
\hline Required storage area & ha & 1,200 & 900 \\
Gilów TSF & ha & $600-850$ & $600-850$ \\
New TSF & ha & $600-350$ & 150 \\
Final total TSF's area & ha & 1,200 & $780-1,000$ \\
\hline
\end{tabular}

The following solutions have been selected to reach additional required storage volume:

- Increase of the Żelazny Most TSF dams to the elevation of $195 \mathrm{~m}$ asl (approximately $184 \mathrm{M} \mathrm{m}^{3}$ ) with simultaneous expansion of TSF to the south (about $150 \mathrm{M} \mathrm{m}^{3}$ );

- Increase of the Żelazny Most TSF dams to the elevation of $195 \mathrm{~m}$ asl (approximately $184 \mathrm{M} \mathrm{m}^{3}$ ) with simultaneous reactivation of TSF Gilów (about $180 \mathrm{M} \mathrm{m}^{3}$ );

- Reactivation of the TSF Gilów together with construction of a new TSF Juszowice.

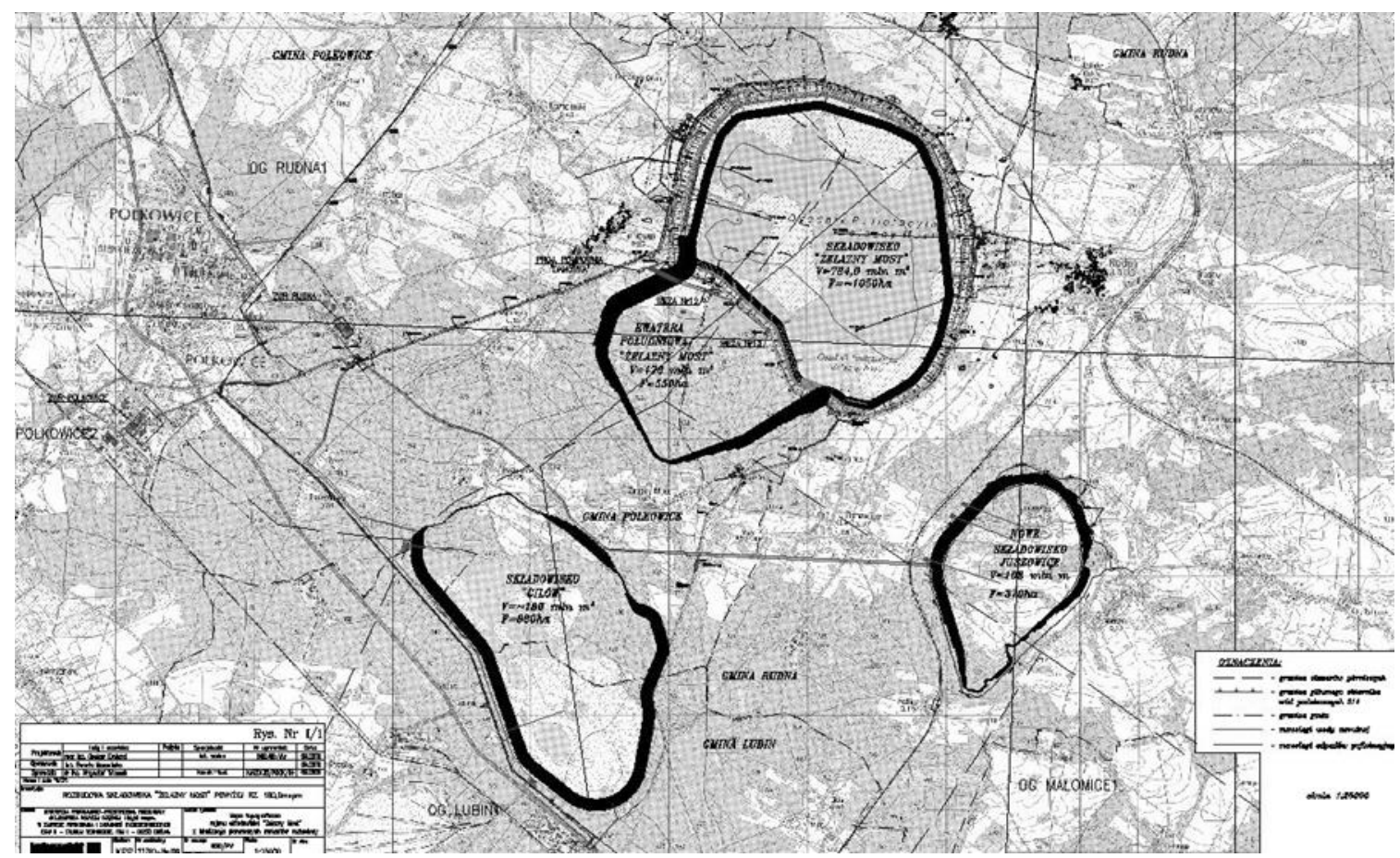

Figure 8 Concepts of tailings deposition after 2020

In 2010, in connection with the proactive mining activities in the area of the old storage site Gilów and the risk of unavailability of this location within the required time, further work focused on enlarging capacity of the TSF Żelazny Most by limited increase of dams and expansion to the south, creating a virtually new TSF Kwatera Południowa (Southern Extension TSF) adjacent to the TSF Żelazny Most.

\section{$5 \quad$ New Tailings Storage Facility Kwatera Południowa - Variant C}

The Southern Extension TSF, with its limited area, requires the introduction of thickened tailings technology. KGHM are therefore considering the discharge of thickened tailings to the proposed Southern Extension of the Żelazny Most TSF. During the last 3 years various studies have been completed, the most recent in 2016 based on new concept studies principally by Golder Associates, Paterson and Cooke, and Outotec.

It is understood from reviewing the information presented that KGHM have to implement the Southern Extension to reduce the rates of rise of the Main Structure and achieve the total capacity required for the 
Life of Mines(s) when considering a final elevation of $195 \mathrm{~m}$ asl. Thickened tailings discharge into the Southern Extension is required to reduce the rate of rise of this facility.

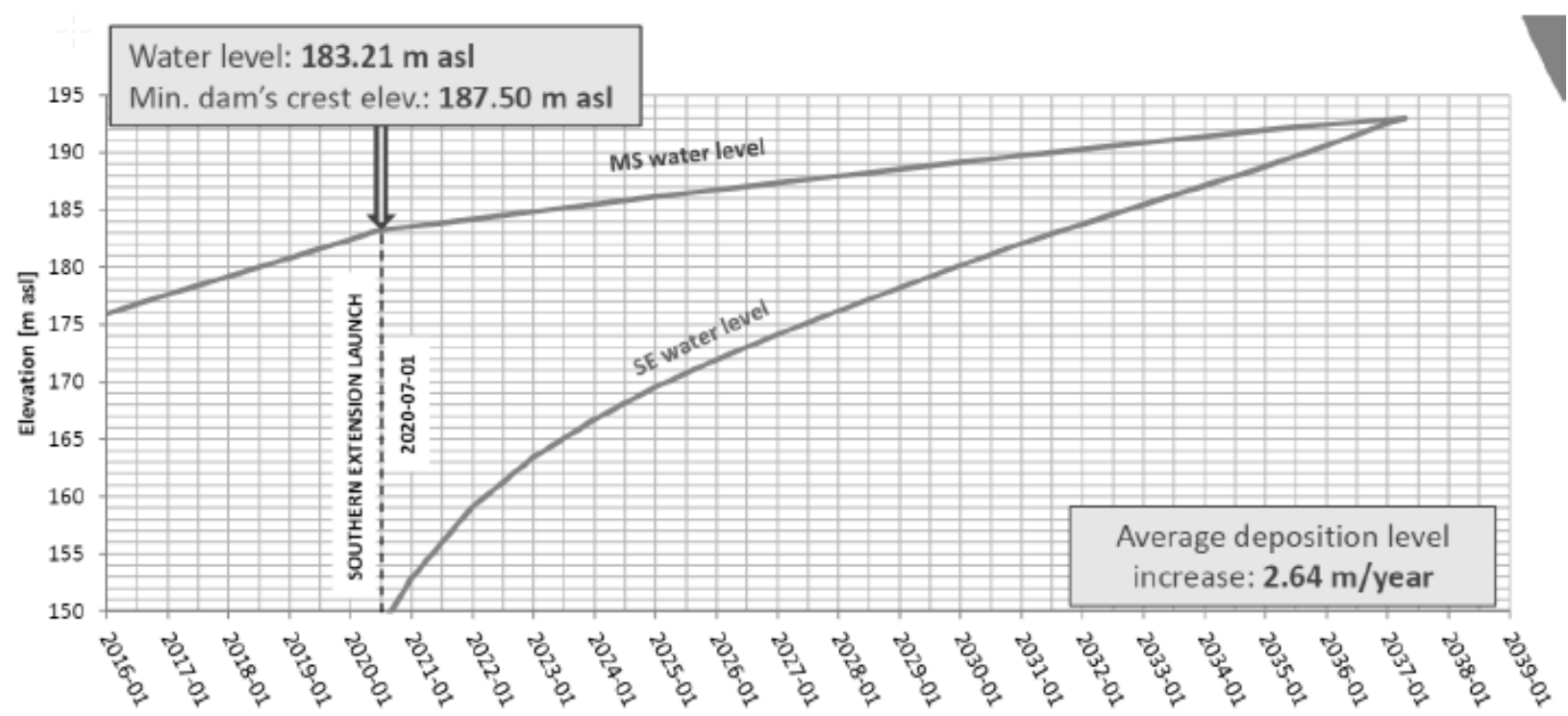

Figure 9 Main Structure and Southern Extension - Deposition Schedule

\subsection{Dredging}

In order to meet the requirement to deposit thickened tailings in the Southern Extension, KGHM have considered the use of dredges to remove semi consolidated tailings from the Main Structure and deposit these denser tailings within the Southern Extension.

\subsection{Tailings Disposal Methodology}

It is understood that the Żelazny Most facility has operated using this methodology since the late 1970's and based on the previous points that the cost associated with tailings storage are very low. Changing this philosophy of operation to a completely different type of disposal system is considered to be challenging for the development and operation of Żelazny Most TSF going forward. Infrastructure on and around the TSF is required, cyclone packs, pumps, thickeners, agitation tanks, dredges, pipework managing different concentrations of tailings and flow rates, and together with the Southern Extension development, are all new items which KGHM will find challenging to operate harmoniously to achieve their final goals.

One other important consideration, and that is relatively unique to Żelazny Most, is the delivery of three different streams of tailings each having different properties. At present the tailings are directly discharge, but the complexity of operation of the proposed infrastructure will depend on the variability of these streams.

\subsection{Methodology}

- All wall construction for the Southern Extension is to be done via cycloning, and not via natural spigot segregation. The specification of this sand is $30 \%$ passing 50 microns.

- Thickened tailings are required to be deposited in the Southern Extension, the specific concentration is not specified and does not have to be a paste tailings.

Considering the previous two points, the following minimum infrastructure is required to meet these goals.

- Operation of cyclones, either as a central location (cyclone packs) or via in-situ crest cycloning.

- Operation of a thickener(s) to increase the concentration of solids being discharged to the Southern Extension and/or Main Structure. 
One aspect that is not mentioned in some studies (but has been recognized by Paterson and Cooke's prefeasibility study and commented by Outotec in their latest report) is that there is no requirement to thicken all tailings, only the tailings to be deposited in the Southern Extension. This is a suitable opportunity for KGHM to consider a staged development to continue with the operation of Żelazny Most as-is, and only thicken tailings that require discharge to the Southern Extension.

Considering that the Main Structure can operate until $195 \mathrm{~m}$ asl, based on current operational practices, this is an approximate 26 years of further operation. Developing cyclone and thickener capacity only for the Southern Extension is advantageous for KGHM, it will not only delay expenditure and reduce risk, it will allow a smoother transition for operational change for the Main Structure in the future. It also prevents changing the infrastructure and deposition methodology of the Main Structure so as to maintain the option to continue current practices for the entire three plant flows for any unforeseen event. In the future if there is a need to thicken all tailings, to both the Southern Extension and Main Structure, KGHM will have gained experience in their thickening and disposal capabilities and be able to apply knowledge and optimizations in any future thickener or dewatering developments.

Considering the 26 year time frame, the further this expansion to full flow thickening is delayed, dewatering technology may be more advanced and economic compared to current day technologies.

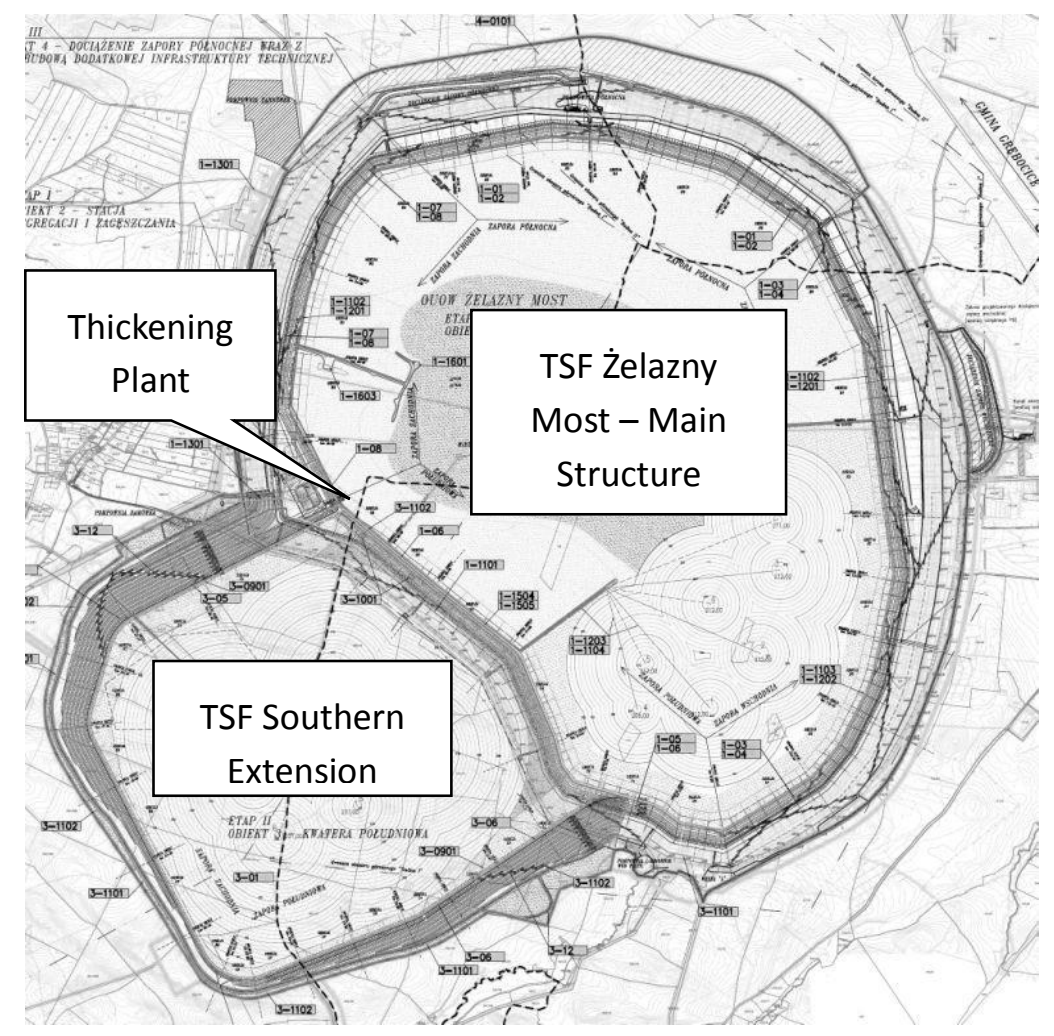

Figure 10 Southern Extension TSF and TSF Żelazny Most thickened tailings deposition plan

Works are currently underway on the development of the final optimal thickening technology, design of the Tailings Thickening and Classification Plant, design of Southern Extension TSF and adaptation of the TSF Żelazny Most Main Structure to thickened tailings deposition.

\section{Conclusions}

Surface deposition of tailings is always associated with the involvement of a large surface area. Today, active mining activity in the area, dense population and considering highly regulated environmental conditions, the acquisition of new land for tailings storage is extremely difficult. The paper presents a long, laborious and not yet completed methodology which KGHM and DHV Hydroprojekt had to develop to extend the life of the 
Żelazny Most TSF. In the KGHM ore production process there is no problem with the lack of water for hydro transport, nevertheless it is thickened tailings technology which finally permitted a coherent program of enlarging the storage area for KGHM.

Any unexpected disruption in tailings deposition results in immediate production cutbacks. With such an important role of KGHM for the economy in the region and throughout the country, such a scenario is unacceptable. It should be emphasized that KGHM Polska Miedź S.A. is a significant entrepreneur in the area, providing employment to 18,000 people. Another 10,000 people are the employees of KGHM Capital Group and taking into consideration co-operating companies, KGHM provides employment for 100,000 people.

As a result of multithreaded analyzes which took into account the technical conditions of safety, social, environmental, formal, legal and economic, DHV Hydroprojekt recommended to lift TSF Żelazny Most dams to the elevation $195 \mathrm{~m}$ asl, which according to previous studies and observations is possible to achieve while maintaining the required level of safety and to build the new Southern Extension TSF. This solution combined with the conversion of depositing to a higher concentrated tailings has another very important advantage, namely the reserve capacity that will be generated, allowing acquisition of all of the tailings stream for a period of up to 10 years.

Considering first and foremost the social and economic circumstances, in 2013 the board of KGHM decided to build the Southern Extension TSF and introduce thickening technology, which on the one hand entails considerable financial outlays, however, ensures uninterrupted operation of the mine and tailings storage facility.

\section{Acknowledgements}

The authors acknowledge KGHM Polska Miedź S.A. for their permission to publish the data and cooperation and DHV Hydroprojekt TH department staff for support.

\section{References}

Nicholson, D., Tse, C. and Penny, C. 1999, 'The Observational Method in ground engineering - principles and applications', Report 185, CIRIA, London.

Terzaghi, K., and Peck, R.B. 1967, 'Soil Mechanics in Engineering Practice', John Wiley and Sons, 729p. 